\title{
PCR-based DGGE and FISH analysis of methanogens in an anaerobic closed digester tank for treating palm oil mill effluent
}

\author{
Meisam Tabatabaei* \\ Department of Bioprocess Technology \\ Faculty of Biotechnology and Biomolecular Sciences \\ University Putra Malaysia 43400, Serdang \\ Selangor, Malaysia \\ Tel: 60389467590 \\ Fax: 60389467593 \\ E-mail: meisam_tab@yahoo.com \\ Mohd Rafein Zakaria \\ Department of Bioprocess Technology \\ Faculty of Biotechnology and Biomolecular Sciences \\ University Putra Malaysia 43400, Serdang \\ Selangor, Malaysia

\section{Raha Abdul Rahim} \\ Department of Cell and Molecular Biology \\ Faculty of Biotechnology and Biomolecular Sciences \\ Universitiy Putra Malaysia 43400, Serdang \\ Selangor, Malaysia

\section{André-Denis G. Wright} \\ CSIRO Livestock Industries \\ Queensland Bioscience Precinct \\ St. Lucia, Queensland 4067, Australia
}

\section{Yoshihito Shirai}

Graduate School of Life Science and Systems Engineering Kyushu Institute of Technology

Wakamatsu-ku, Kitakyushu 808-0196, Japan

\section{Norhani Abdullah}

Department of Microbiology Faculty of Biotechnology and Biomolecular Sciences

University Putra Malaysia 43400, Serdang Selangor, Malaysia

\section{Kenji Sakai}

Laboratory of Soil Microorganisms

Department of Plant Resources

Graduate School of Bioresources and Bioenvironmental Sciences

Kyushu University

Higashi-ku, Fukuoka, Japan

\section{Shinya Ikeno}

Graduate School of Life Science and Systems Engineering Kyushu Institute of Technology

Wakamatsu-ku, Kitakyushu 808-0196, Japan

\section{Masatsugu Mori}

Laboratory of Soil Microorganisms

Department of Plant Resources

Graduate School of Bioresources and Bioenvironmental Sciences Kyushu University

Higashi-ku, Fukuoka, Japan 


\author{
Alawi Sulaiman \\ Department of Food and Process Engineering \\ Faculty of Engineering \\ University Putra Malaysia 43400, Serdang \\ Selangor, Malaysia \\ Mohd Ali Hassan \\ Department of Food and Process Engineering \\ Faculty of Engineering and \\ Department of Bioprocess Technology \\ Faculty of Biotechnology and Biomolecular Sciences \\ University Putra Malaysia 43400, Serdang \\ Selangor, Malaysia
}

Financial support: FELDA (Federal Land Development Authority), MOSTI (Ministry of Science, Technology and Innovation, Malaysia) and JSPS (Japan Society for the Promotion of Science).

Keywords: anaerobic digestion, DGGE, FISH, methanogens, POME.

Abbreviations: $C C D$ : charge-coupled device

CDM: clean development mechanism
CDT: closed digester tank
COD: chemical oxygen demand
DGGE: denatured gradient gel electrophoresis
FISH : fluorescent in situ hybridization
NCBI: National Center for Biotechnology Information
PBS: phosphate buffer saline
PCR: polymerase chain reaction
POME: palm oil mill effluent
RFLP: restriction fragment length polymorphism
rRNA: ribosomal RNA
SEM: scanning electron microscopy
UASB: upflow anaerobic sludge blanket
VFA: volatile fatty acids

16S ribosomal RNA (rRNA)-targeted fluorescent in situ hybridization combined with polymerase chain reaction (PCR)-cloning, light microscopy using Gram stains, scanning electron microscopy and denatured gradient gel electrophoresis were used to reveal the distribution of methanogens within an anaerobic closed digester tank fed with palm oil mill effluent. For specific detection of methanogens, 16S rRNA-cloning analysis was conducted followed by restriction fragment length polymorphism (RFLP) for presumptive identification of methanogens. To cover the drawbacks of the PCRcloning study, the organization of the microorganisms was visualized in the activated sludge sample by using fluorescent oligonucleotide probes specific to several different methanogens, and a probe for bacteria. In situ hybridization with methanogens and bacterial probes and denatured gradient gel electrophoresis within activated sludge clearly confirmed the presence of Methanosaeta sp. and Methanosarcina sp. cells.
Methanosaeta concilii was found to be the dominant species in the bioreactor. These results revealed the presence of possibly new strain of Methanosaeta in the bioreactor for treating palm oil mill effluent called Methanosaeta concilii SamaliEB (Gene bank accession number: EU580025). In addition, fluorescent hybridization pictured the close association between the methanogens and bacteria and that the number of methanogens was greater than the number of bacteria.

Ardern and Lockett developed the first activated sludge system for purification of wastewater in Manchester (Moter and Göbel, 2000). However, the role of microbial consortia in this process is still not completely understood. Culturebased techniques were found to be too selective to give a comprehensive and authentic picture of the entire microbial community as it has been estimated that the majority (over 99\%) of bacteria in nature cannot be cultivated by using traditional techniques (Rondon et al. 2000). As a

*Corresponding author 


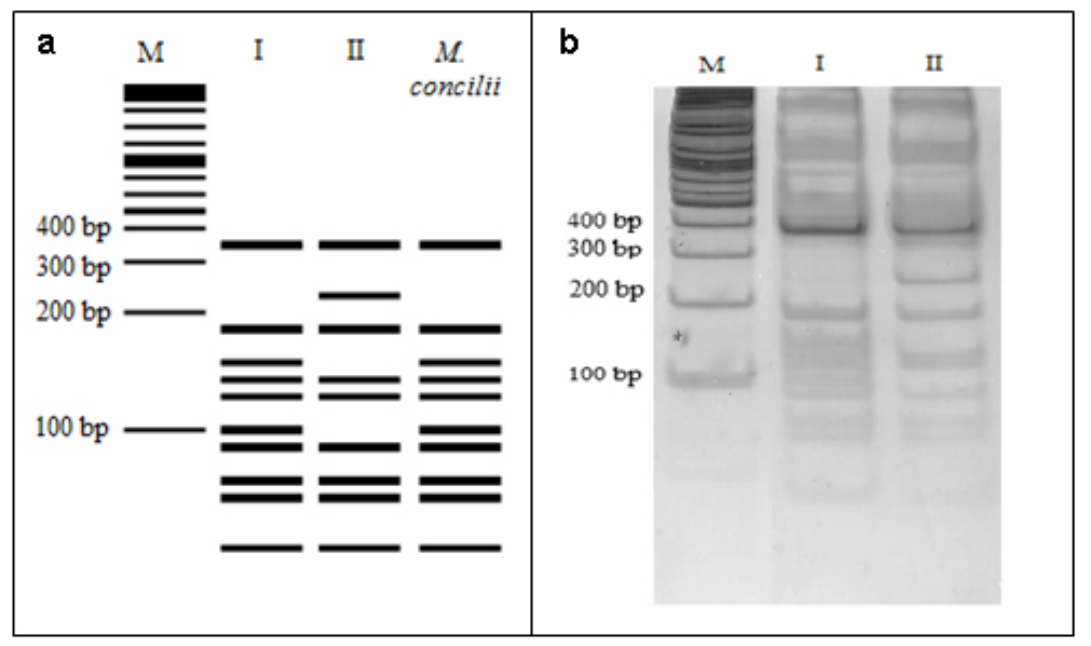

Figure 1. Calculated (a) and observed (b) Haelll RFLP patterns that occurred among 237 cloned archaeal 16S rRNA fragments from sludge taken from bottom and middle of the bioreactor and the recycling tank. Fragment sizes were inferred from DNA sequences of representative clones. M: $100 \mathrm{~kb}$ molecular mass marker (Fermentas, Hanover, Maryland, USA); RFLP patterns were labeled 'I'; SamaliEB, II; Samali15' and M. concilii (M59146).

consequence, it is very unlikely that collections of bacterial isolates are representative of in situ diversity and community structure.

Therefore, ribosomal RNA (rRNA)-based population methods have been a very useful tool to analyze such environments like bioreactors and wastewater treatment plants. Sequences that were retrieved from molecular analysis using polymerase chain reaction (PCR)-based techniques were used to create fluorescently labelled oligonucleotide probes for fluorescence in situ hybridization (FISH) investigation of microorganisms, e.g. in activated sludge (Amann et al. 1996; Schuppler et al. 1998). As this technique allows simultaneous visualization, identification, enumeration and localization of individual microbial cells, FISH is considered useful for many applications in all fields of microbiology. Members of the domain Archaea, particularly methanogens and their association with bacteria have been found by FISH in anaerobic digesters and within anaerobic sludge samples.

Denaturing gradient gel electrophoresis (DGGE) of $16 \mathrm{~s}$ rRNA have been used for the characterization of bacterial communities in activated sludge (Watanabe et al. 1998; Watanabe et al. 1999). The rRNA clone library and DGGE method can provide direct sequence information useful for the assessment of phylogenetic groups of methanogens present. However, the reliability and reproducibility of these methods are affected by technical factors like efficiency of DNA extraction, PCR biases, and selection of clones. Also, the relative abundance of different 16s rRNA clones amplified from a mixed population depends upon genome size and the rRNA gene copy number of bacteria present, and thus are not necessarily reflective of the relative population of different taxa (Fogel et al. 1999). The combined use of FISH, DGGE and $16 \mathrm{~S}$ rDNA-cloning methods allowed analyzing of bacterial communities more precisely. Besides, the localization of microorganisms by FISH can prove the symbiotic relationship between specific microorganisms.

Palm oil mill effluent (POME) is one of the world most polluting wastewater in Malaysia and the world. So the anaerobic treatment of POME using anaerobic digesters is of great importance both for methane gas production and clean development mechanism (CDM). Hence, an understanding of the microbial ecology of the bioreactor systems is necessary to monitor the microbial activities. A few reports have shown promising applications of bioreactors and process designs for the treatment of POME (Najafpour et al. 2005; Yacob et al. 2006). However, to our knowledge, no studies have been reported on the microbial ecology of the POME digesters especially of methanogenic archaea in Malaysia. In the breakdown process of organic residues, approximately $70 \%$ of intermediate by-products are converted to acetate which is the main precursor in methane production. Until now, the only acetate-utilizing methanogens identified in anaerobic digestors belongs to the genera Methanosarcina and Methanosaeta (Mladenovska and Ahring, 2000). Filamentous and aggregating types of Methanosaeta spp. have been commonly observed other than Methanosarcina spp. in mesophilic granules (Sekiguchi et al. 2001). It is critical to have an accurate understanding of the microbial population of the bioreactor to provide the optimum growth conditions for the dominant species which could be consequently followed by the highest possible methane production.

The aim of the present work was to determine the methanogen community structure in the anaerobic bioreactor treating POME using 16S rRNA clone library, 


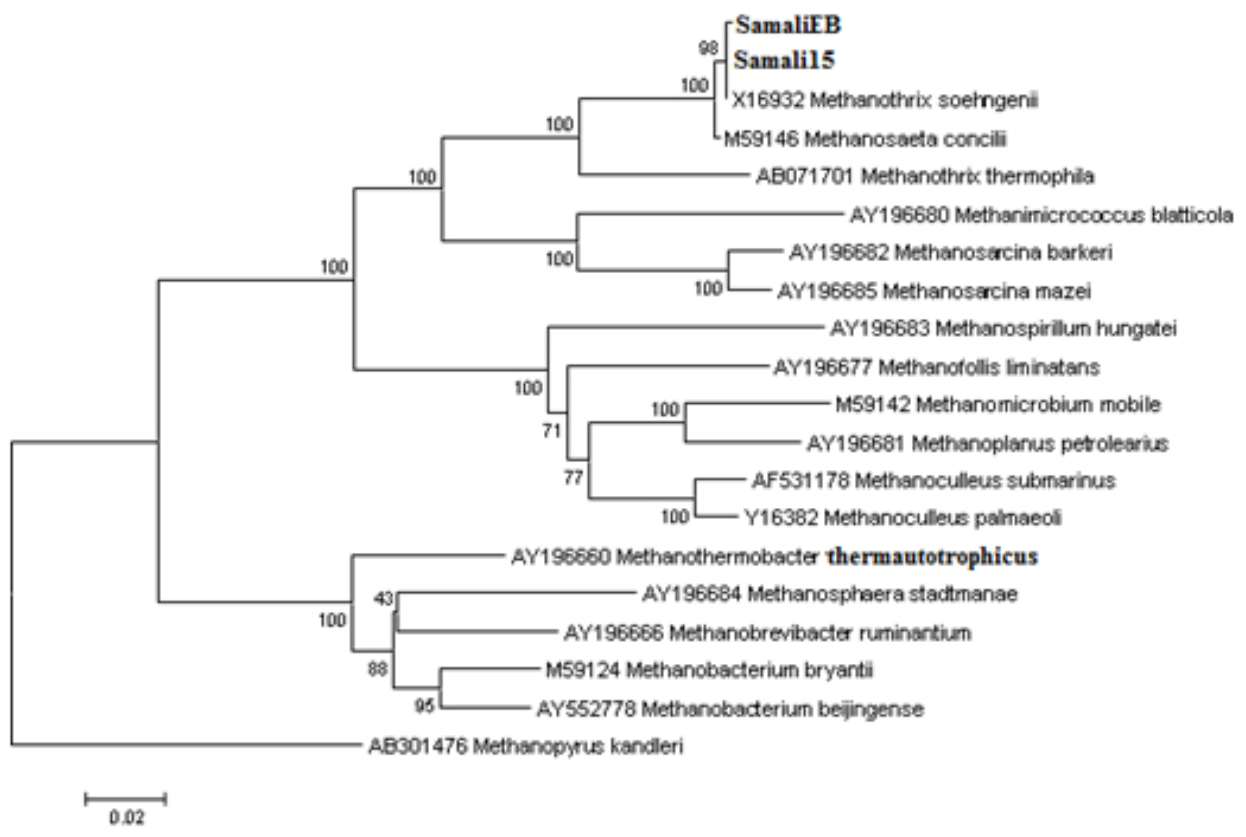

Figure 2. A phylogenetic tree, showing how clones SamaliEB and Samali15 are related to other methanogens.

DGGE analysis, FISH, scanning electron microscopy (SEM) and light microscopy.

\section{MATERIALS AND METHODS}

\section{Bioreactor set-up and sampling}

Activated sludge was collected from a $500 \mathrm{~m}^{3}$ closed digester tank (CDT) for the anaerobic treatment of POME, located in Serting Hillir Palm Oil Mill, Negeri Sembilan, Malaysia. The CDT was operated under mesophilic condition $\left(32-39^{\circ} \mathrm{C}\right)$ for 120 days. The system was

Table 1. Process parameters recorded at the time of sampling, i.e. after 80 days of operation at the steady-state condition.

\begin{tabular}{|l|c|}
\hline \multicolumn{1}{|c|}{ Parameters } & Value \\
\hline $\mathrm{pH}$ of the digester & 7.1 \\
\hline Total Solid g/L & 22 \\
\hline Organic Loading Rate applied $\mathrm{kgCOD} / \mathrm{m}^{3}$ day & 4.5 \\
\hline Influent COD mg/L & 41,300 \\
\hline VFA mg/L & 517 \\
\hline Acetic acid mg/L & 275 \\
\hline COD removal efficiency \% & 93 \\
\hline
\end{tabular}

equipped with a closed digester tank, settling tank, pumps, and flow meters for biogas and the effluent. There were three sampling ports at the top, in the middle and at the bottom of the CDT. The sludge sample was obtained from middle sampling port. The process parameters recorded at the time of sampling are shown in Table 1.

The chemical oxygen demand (COD), volatile fatty acids (VFA), $\mathrm{pH}$, alkalinity analyses were carried based on standard method (APHA, 2005). Acetate concentration was measured by high performance liquid chromatography (SPD-10A, UV-VIS Detector; LC-10 AS Liquid Chromatography Shimadzu). The temperature, biogas mass-flow and raw POME mass-flow were recorded using an integrated on-line data recording system (EndressHauser Ecograph system, Germany). The methane concentration in biogas was detected on-site using a methane gas analyzer (XP314A, Shin-Cosmos Electrics Co. Ltd., Japan). Influent COD ranged between $30,000 \mathrm{mg} / \mathrm{L}$ to $90,000 \mathrm{mg} / \mathrm{L}$ across this study and it was recorded 41,300 $\mathrm{mg} / \mathrm{L}$ at the time of sampling on the day $80^{\text {th }}$ of the operation at the steady-state condition (Table 1). The VFA concentration at the sampling time was $517 \mathrm{mg} / \mathrm{L}$ with the acetate concentration of $275 \mathrm{mg} / \mathrm{L}$. The activated sludge samples were transported to the laboratory in sterile $50 \mathrm{ml}$ falcon tubes placed in crushed ice and stored at $-20^{\circ} \mathrm{C}$ until use.

\section{DNA extraction and PCR amplification}

DNA was extracted from activated sludge following the method of Bourrain et al.(1999) and 16S rDNA was 
amplified using the Wright and Pimm (2003) methanogenic specific primers Met86F (5'-GCTCAGTAACACGTGG3') and Met1340R (5'-CGGTGTGTGCAAG GAG-3'). PCR reactions $(25 \mu \mathrm{L})$ were set up in $0.2 \mathrm{~mL}$ thin-walled Eppendorf ${ }^{\circledR}$ tubes, containing 100 ng sludge DNA, $10 \mathrm{X}$ Taq DNA polymerase buffer, $0.5 \mu \mathrm{L}$ of $10 \mathrm{mM}$ dNTP mix (Fermentas, Maryland, USA), $0.5 \mu \mathrm{l}$ of $10 \mathrm{mM}$ dNTPs, 2.5 $\mu 1$ of $25 \mathrm{mM} \mathrm{MgCl}_{2}, 0.5 \mu \mathrm{l}$ of each methanogen primer and $0.2 \mu \mathrm{l}$ of $5 \mathrm{U}$ AmpliTaq DNA polymerase (Fermentas, Maryland, USA). DNA templates from three sludge samples obtained from the bottom and middle of the bioreactor, and from the recycling tank were amplified separately for cloning. Samples were amplified using a Perkin Elmer Gene Amp system 9600. Each PCR cycle consisted of $94^{\circ} \mathrm{C}$ for $40 \mathrm{sec}, 54^{\circ} \mathrm{C}$ for $50 \mathrm{sec}, 72^{\circ} \mathrm{C}$ for 90 sec. On the $35^{\text {th }}$ cycle, the elongation step was increased to $10 \mathrm{~min}$ at $72^{\circ} \mathrm{C}$.

\section{Cloning 16S rDNA}

PCR products were purified from a $1 \%$ agarose gel using a gel extraction kit according to the manufacturer's instructions (Qiagen, Germany). The recovered PCR fragment was cloned into pTZ57R vector (Fermentas, Maryland, USA), and transformed into Escherichia coli TOP10 competent cells (Invitrogen, Carlsbad, CA). White colonies were randomly selected from plates and recombinant plasmids identified by size selection on a $1 \%$ agarose gel prior to restriction fragment length polymorphism (RFLP) analysis.

\section{RFLP and sequences analysis}

Cloned PCR products were digested separately with HaeIII (Fermentas, Maryland, USA) in $20 \mu \mathrm{l}$ reaction volumes containing $10 \mu \mathrm{l}$ of PCR product, $2 \mu \mathrm{l} \times 10$ reaction buffer and 10 units of restriction endonuclease in sterile ultrapure water. Digested PCR products were incubated for $1 \mathrm{hr}$ at $37^{\circ} \mathrm{C}$ and digested fragments were separated using a $10 \%$ polyacrylamide gel $(\mathrm{w} / \mathrm{v})$. The resulting bands were visualized by silver-staining and each clone was assigned to an RFLP group based upon the banding patterns. Two groups (group I and group II) were assigned.

For each RFLP type, the 16S rRNA insert of a few representative clones were sequenced. The recombinant plasmids were extracted using the Qiagen plasmid DNA extraction kit (Qiagen, Germany) according to the manufacturer's instructions. Approximately 27 nucleotides were sequenced using an ABI 3730 XL DNA Sequencer. Chromatograms were edited using Chromas software (Technelysium, Australia), while CHECK_CHIMERA software (Maidak et al. 1997) was used to scan for potential chimeric sequences. The sequences were compared to known 16S rRNA sequences in the GenBank ${ }^{\mathrm{TM}}$ database, using the basic logical alignment search tool (BLAST) to locate nearly exact matches in the GenBank database. DNA sequences were aligned using the program CLUSTAL W (Thompson et al. 1994) and further edited manually. Phylogenetic analyses were performed using the neighborjoining (NJ) method using the MEGA ver. 3.1 (Kumar et al. 2004).

\section{PCR-based DGGE fingerprinting of methanogens}

For each RFLP group, one representative clone was selected for further study. DGGE-PCR reactions were performed on sludge DNA, as well as on the extracted plasmids from representative clones. The aim was to obtain the DGGE profiles for the archaeal and methanogenic species in the POME anaerobic bioreactor. Therefore, universal DGGE methanonenic and archaeal primers were used in the amplification reactions. The universal archaeal primers PARCH340f and PARCH519r based on the E. coli 16S rRNA gene sequence and methanogenic primers $0357 \mathrm{~F}$ and 0691R were used to amplify $179 \mathrm{bp}$ and $334 \mathrm{bp}$ fragments (Watanabe et al. 2004), respectively. The GC clamp, 5'-CGC CCG GGG CGC GCC CCG GGC GGG GCG GGG GCA CGG GGG-3' as described by Chan et al. (2001), was included on the 5 end of the forward primer

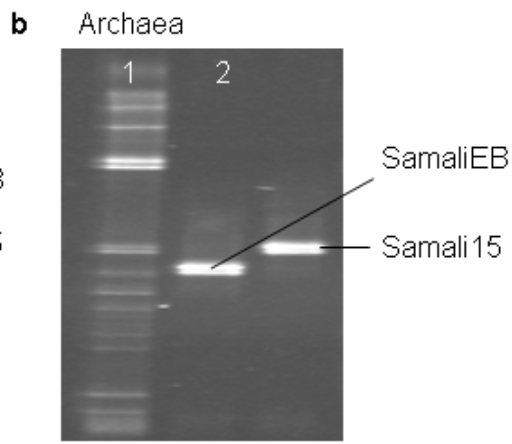

Figure 3. PCR-based DGGE fingerprints of the methanogens-denaturants gradient from 40 to $60 \%$ - (a) and archaeadenaturants gradient from 50 to $60 \%$ - (b) present in the CDT treating POME using methanogenc and archaeal primers.

Lane 1 (a): Methanogens present in the anaerobic bioreactor; Lane 1 (b) Archaea present in the anaerobic bioreactor; Lane 2 and 3 : Methanosaeta concilii (SamaliEB and Samali15). 


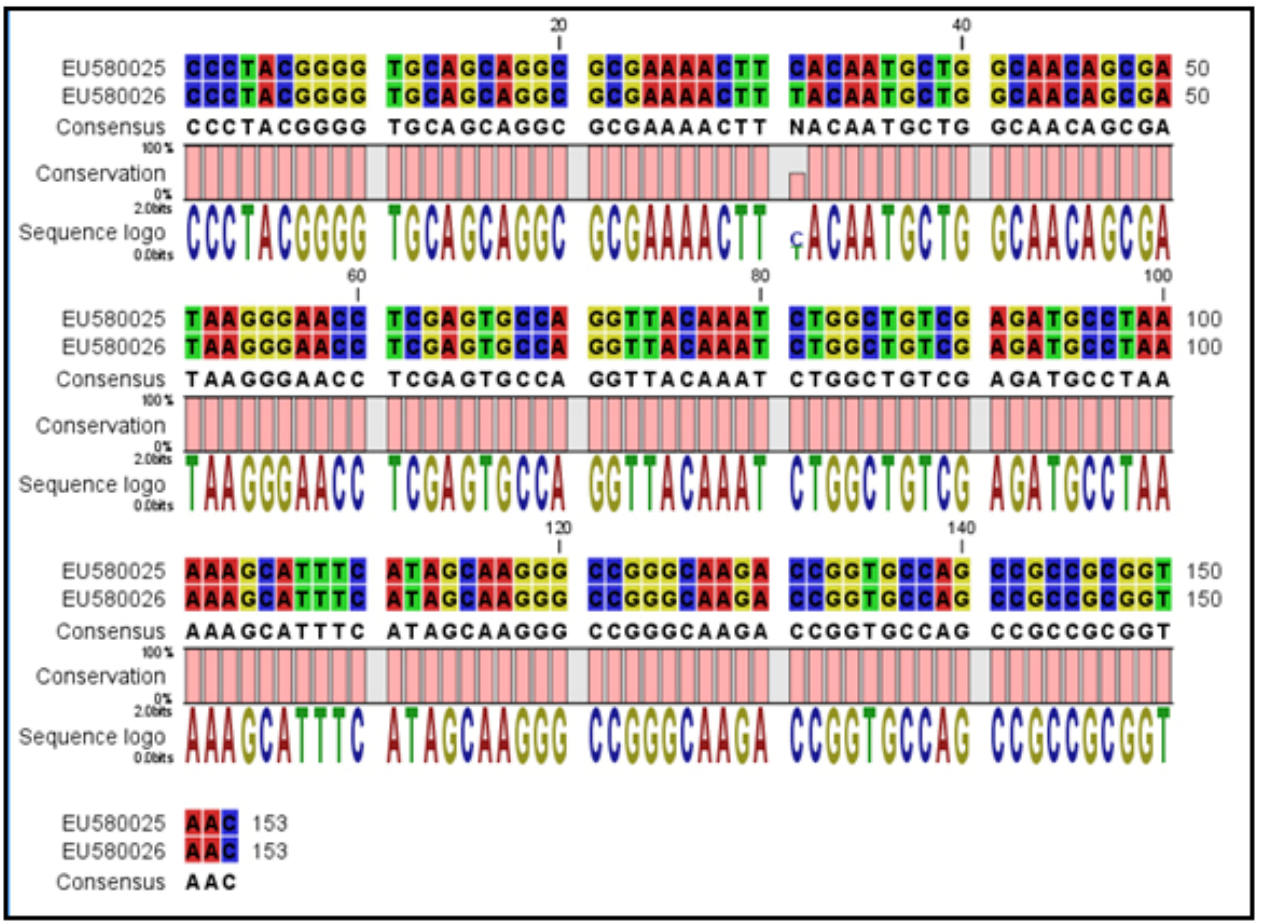

Figure 4. Alignment of the Methanosaeta concilii clone SamaliEB (EU580025) and Methanosaeta concilii clone Samali15 (EU580026) amplified by archaeal primers PARCH340f and PARCH519r using CLC Free Workbench version 4.1.2 (CLC Bio A/S, Denmark).

PARCH340f and 0357F to enable the separation of the fragments using DGGE. PCR reactions for both primer sets were performed in $50 \mu \mathrm{l}$ reaction volumes containing $0.5 \mu 1$ of Taq DNA polymerase (5 U/ $\mu$ l) (Fermentas, Maryland, USA), $5 \mu$ of $10 \mathrm{x}$ PCR reaction buffer, $0.5 \mu \mathrm{l}$ of each of the primers $(10 \mathrm{mM}), 5 \mu \mathrm{dNTPs}(10 \mathrm{mM}), 4 \mu \mathrm{l}$ of $\mathrm{Mgcl}_{2}$ (Fermentas, Maryland, USA) and $1 \mu \mathrm{l}$ of the extracted DNA or plasmid. The PCR amplification conditions for the primer sets were as follows: initial denaturation was performed at $94^{\circ} \mathrm{C}$ for $3 \mathrm{~min}$; followed by denaturation at $94^{\circ} \mathrm{C}$ for $1 \mathrm{~min}$; annealing at $60^{\circ} \mathrm{C}$ for archaeal primers and $58^{\circ} \mathrm{C}$ for methanogenic primers for $1 \mathrm{~min}$; and chain elongation at $72^{\circ} \mathrm{C}$ for $2 \mathrm{~min}$. On the $35^{\text {th }}$ cycles, the final elongation step was performed at $72^{\circ} \mathrm{C}$ for $8 \mathrm{~min}$. The amplified products were checked on $1 \%$ agarose gels and visualized under UV light.

\section{DGGE}

DGGE (DCode System; BioRad, Hercules, CA, USA) was used to separate the $179 \mathrm{bp}$ and $334 \mathrm{bp}$ PCR products. The initial parameters for the denaturing gradient were optimized empirically. The optimized gradient extended from $40 \%$ to $60 \%$ and $50 \%$ to $60 \%$ of denaturant consisting of $7 \mathrm{M}$ urea and $40 \%$ formamide for methanogens and archaeal PCR products, respectively. This was established in $8 \%$ acrylamide gels. Electrophoresis was performed at $100 \mathrm{~V}$ for $14 \mathrm{hrs}$ at a constant temperature of $60^{\circ} \mathrm{C}$. The DNA was stained with cyber green and visualized under UV light.

\section{Band selection, DNA purification and sequencing}

All DGGE bands from the methanogenic profile were punched out with a sterile pasture pipette and used as a template in a re-amplification using the methanogens primers 0357F and 0691R (Watanabe et al. 2004). The resultant PCR products were purified using the Mag Extractor-PCR and Gel Clean up-kit. (Toyobo, Japan) according to the manufacturer's instructions and sequenced using an ABI 3730 XL DNA Sequencer at the DNA Sequencing Facility at Kyushu Institute of Technology, Japan. The sequences obtained were compared to $16 \mathrm{~S}$ rRNA gene sequences in the National Center for Biotechnology Information (NCBI) database using the BLAST.

\section{FISH}

To directly analyze methanogens populations in an anaerobic digester sludge sample, the probe MSMX860, complementary to the 16S rRNA of some methanogens including Methanosarcina spp., Methanococcoides spp., Methanolobus spp., Methanohalophilus spp. and Methanosaeta spp. was used (Crocetti et al. 2006). To target the sludge bacteria, the 16S rRNA probe EUB338 for the domain bacteria was used (Amann et al. 1990). Oligonucleotides and their fluorescent derivatives (5 labelled with either FITC or rhodamine) were purchased from Hokkaido System Science (Sapporo). 


\section{Fixation and permeabilization of the cells}

Cells were fixed and hybridized using the protocol reported from Amann (1995) with some modification (Sakai et al. 2004). The sludge sample was fixed in $3 \%$ paraformaldehyde/phosphate buffer saline (PBS) (PBS; 130 $\mathrm{mM} \mathrm{NaCl}, 10 \mathrm{mM}$ sodium phosphate buffer, $\mathrm{pH}$ 7.0) for 1$3 \mathrm{hrs}$ at $4^{\circ} \mathrm{C}$, pelleted by centrifugation $(3500 \mathrm{x} \mathrm{g}, 15 \mathrm{~min}$, $4^{\circ} \mathrm{C}$ ) and then stored in a 1:1 mixture of ethanol and PBS. Fixed cell suspensions were diluted using an ethanol/PBS mixture $(8 \mu \mathrm{l})$ and were spotted on coated glass slides $(12$ wells per slide, Cel-Line; Erie Scientific, Portsmouth, New Hampshire, UK), dried at $46^{\circ} \mathrm{C}$ for $30 \mathrm{~min}$ and immersed for 3 min each in $50 \%, 80 \%$, and $99 \%(\mathrm{v} / \mathrm{v})$ ethanol. Cell smears were covered with $20 \mu \mathrm{l}$ of lysozyme $(50 \mathrm{mg} / \mathrm{ml}$ PBS; $37^{\circ} \mathrm{C}, 30 \mathrm{~min}$ ). Enzymatic digestion was terminated by thoroughly rinsing the slides with distilled water followed by air-drying at room temperature $\left(25 \pm 2^{\circ} \mathrm{C}\right)$.

\section{Whole cell fluorescent in situ hybridization}

Samples in $8 \mu \mathrm{l}$ of hybridization buffer [0.9 M NaCl, 20 $\mathrm{mM}$ Tris- $\mathrm{HCl}$ (pH 7.2), $0.01 \%$ SDS, $60-120 \mathrm{ng}$ of probe, 0 $30 \%$ formamide] were applied to the wells on the slides and incubated at an appropriate temperature for $2 \mathrm{hrs}$ in an equilibrated humid chamber. Unbound probes were removed from the slide by rinsing with $1 \mathrm{ml}$ of washing solution $(20 \mathrm{mM}$ Tris- $\mathrm{HCl}, 0.01 \% \mathrm{SDS}, 450 \mathrm{mM} \mathrm{NaCl}, 5$ $\mathrm{mM}$ EDTA). The slides were then incubated at $48^{\circ} \mathrm{C}$ for 20 min in $50 \mathrm{ml}$ of washing solution, rinsed briefly with distilled water, air-dried and mounted with SlowFade antifading reagent (Molecular Probes, OR, USA). Fluorescence was observed using an epifluorescence microscope (BX50; Olympus, Tokyo, Japan) and photomicrographs were taken using a chilled 3-charge- coupled device (CCD) color camera $(640$ x 483 pixels, C5810; Hamamatsu Photonics, Shizuoka, Japan). Fluorostained cells were observed and counted in duplicate wells for appropriately diluted samples and those in five randomly selected fields for each those two replications (1000-fold magnification) were recorded on a computer and counted. The concentration of fluoro-stained cells (cells $/ \mathrm{ml}$ ) was calculated as follows:

$$
\left(C \times D \times A_{m}\right) /\left(V \times A_{w} \times F\right)[\text { Eq. 1] }
$$

Where $C$ is the cell number observed on a monitor (cells), $D$ is the dilution rate, $A_{m}$ was the monitor area calculated using an objective micrometer $\left(0.0024 \mathrm{~mm}^{2}\right), V$ was the sample volume spotted in the well $\left(8.0 \times 10^{-3} \mathrm{ml}\right), A_{w}$ was the well area on the glass slide $\left(19.6 \mathrm{~mm}^{2}\right)$ and $F$ was the fixation efficiency (0.82).

\section{Light microscope and scanning electron microscope}

Activated sludge samples were collected from the anaerobic bioreactor, gram-stained and viewed under the optical microscope (Olympus BX50, Japan). Once a sludge sample was collected from the bioreactor, it was prepared for SEM as follows: washed 3 times with $0.1 \mathrm{M}$ cacodylate buffer ( $\mathrm{pH}$ 7.4) for 10 min each time and then fixed with glutaraldehyde $(2.5 \% \mathrm{v} / \mathrm{v})$ in $0.2 \mathrm{M}$ sodium cacodylate buffer ( $\mathrm{pH}$ 7.1) and dehydrated with graded ethanol solutions $(10 \%, 30 \%, 50 \%, 70 \%, 90 \%$, and $100 \%$ ethanol). The samples were dehydrated by the critical point drying method and coated with gold. A Leo 1455 VP scanning electron microscope (Carl-Zeiss, Germany) was used to take the micrographs.

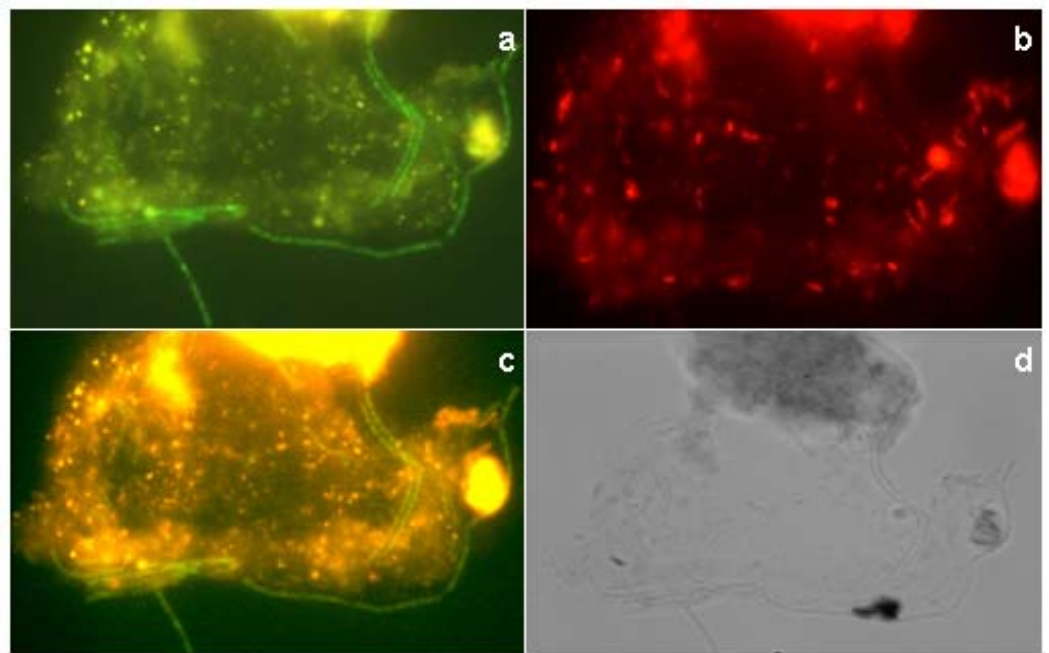

Figure 5. FISH staining of the sludge sample analyzed by confocal laser microscopy of FISH cells (a, b and c) and light microscopy (d).

(a) Methanosaeta concilii; (b) Bacteria; (c) Simultaneously hybridized with rhodamine-labeled bacterial-domain probe (EUB338) (red) and FITC-labeled methanogens probe (MSMX860) (green) showing the consortium between methanogens and bacteria; (d) Light microscopy. 


\section{RESULTS AND DISCUSSION}

\section{Screening the 16S rRNA clone library by RFLP}

16S rRNA was PCR amplified from the DNA extract of sludge taken from an anaerobic bioreactor. From 237 clones screened (84 from the bottom sludge library, 75 from the middle sludge library and 78 from the recycling sludge), all had a DNA insert of the correct size (1260 bp). Two different HaeIII RFLP-patterns were observed from the clone libraries and assigned as group I and II (Figure 1). Representative examples from RFLP group I and II (SamaliEB and Samali15) are shown in Figure 1. RFLP group I contained $97.1 \%$ of clones and $2.9 \%$ fell in group II. The sequences obtained in this study have been deposited in the GenBank database under accession numbers EU580025- to EU580045.

\section{Phylogenetic analysis of representatives from each RFLP group}

Partial DNA sequences were obtained from representative amplicons for each RFLP group. Approximately 27 clones were sequenced (20 from group I and 7 from group II) and were used to search the GenBank nucleotide database with the BLAST search tool. One representative for each RFLP group was included in the phylogenetic tree. The sequence data set contained 20 sequences, including Methanopyrus kandleri that was used as the outgroup (Figure 2).

Matches obtained for each clone sequenced had a similarity of $\geq 99 \%$ with those contained in the GenBank nucleotide database. All RFLP groups I and II clones sequenced were Methanosaeta concilii. Although the RFLP group II clones

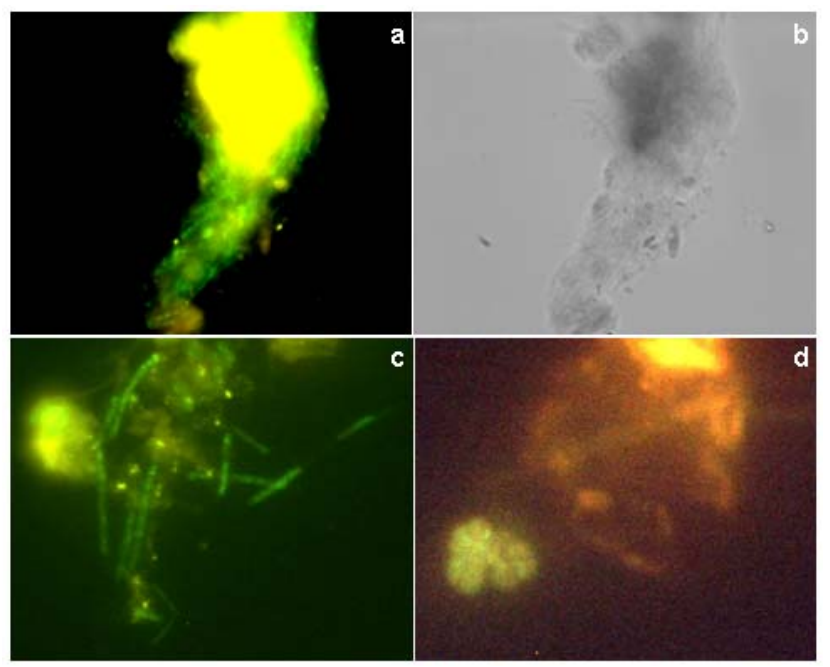

Figure 6. FISH staining of the sludge samples analyzed by confocal laser microscopy of fluorescent in situ -hybridized cells (a, c and d) and light microscopy (b). A fluorescent in situ hybridized floc of Methanosaeta concilii (a); light micrograph of a floc of Methanosaeta concilii (b); filaments of Methanosaeta concilii (c); simultaneously hybridized with rhodamine-labeled bacterial-domain probe (EUB338) (red) and FITC-labeled methanogens probe (MSMX860) (green) showing Methanosarcina (d). had a unique HaeIII restriction profile, partial sequencing of the clones revealed a $99 \%$ identity with $M$. concilii (M59146), a sequence shared by all of the samples in RFLP group I. This distribution of the same species sequence in two different RFLP groups illustrates the limitation of relying on partial DNA sequences as well as RFLP only for representing the diversity of samples contained in a library.

\section{PCR-based DGGE analysis}

A total of five methanogenic bands (EBM1, EBM2, EBM3, EBM4 and EBM5) (Figure 3a) were excised from the methanogenic DGGE fingerprints, re-amplified, purified and sequenced. Yielded sequences (334 bp) were analyzed by CHECK_CHIMERA software (Maidak et al. 1997) to scan for potential chimeric sequences and three were found chimeric. The remaining two (EBM2 and EBM4) were analyzed using the BLAST program. The RFLP groups representatives (SamaliEB and Samali15) were in line with EBM2. Band EBM4 was found to be Methanosarcina. Although band EBM2 correlated with the reference clones SamaliEB and Samali15 (Methanosaeta concilii), it was also excised and sequenced to confirm the identification of the band as Methanosaeta concilii. Band EBM2 showed a 99\% sequence similarity to the uncultured Methanosaeta sp. clone I2 that had been previously found in environmental samples taken from anaerobic biofilms (AB236094, NCBI database). Band EBM4 showed a 97\% sequence similarity to Methanosarcina sp. 48 (EF112192, NCBI database). The methanogenic DGGE pattern showed that the band which belonged to Methanosaetaceae appeared to be denser and sharper than the one of Methanosarcina.

The double bands observed using archaeal primers; PARCH340f and PARCH519r (Figure 3b) was a result of degeneracy of the primers used (Piceno et al. 1999). The archeal PCR products using clones SamaliEB and Samali15 as DNA template did not align on the DGGE gel with the band related to SamaliEB lying lower which was due to a single nucleotide difference between the two amplicons (Figure 4). As shown in the Figure 4, one base pair G/C in SamaliEB is replaced with A/T in Samali15. As a matter of fact, DNA fragments richer in $\mathrm{G} / \mathrm{C}$ are more stable and remain double-stranded until reaching higher denaturant concentrations (lower levels of the gel). Double-stranded DNA fragments migrate better in the acrylamide gel, while denatured DNA molecules become effectively larger and stop in the gel. In this study, a DNA fragment of higher $\mathrm{G} / \mathrm{C}$ content stoped at a lower level of gel and by providing a narrow range of optimized gradient $(50 \%$ to $60 \%)$, a subtle difference between the DNA fragments known as single nucleotide polymorphism (SNP) was detected. This confirmed the RFLP results which found clone SamaliEB to be a different strain of Methanosaeta concilii in comparison with the other clones including clone Samali15 and the gene bank database. In combination with the DGGE fingerprint using Methanogens primers, just two of the archaeal bands 


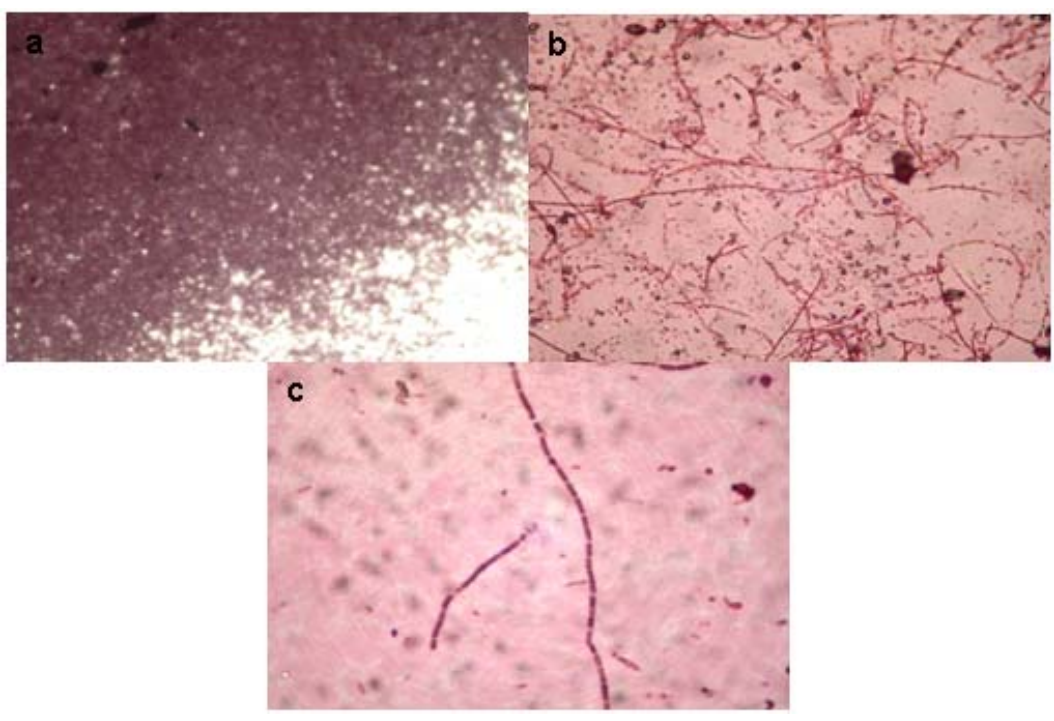

Figure 7. Light micrographs of POME sludge at a magnification of (a) $10 \mathrm{x}$; (b) $40 \mathrm{x}$; (c) $100 \mathrm{x}$. Gram staining test showed that the filamentaous-like Methanosaeta sp. were dominant species in the CDT sludge.

should represent methanogenic archaea (archaeal bands were not analyzed).

\section{Analysis of sludge sample by FISH}

Under optimal hybridization conditions, methanogens and bacteria were specifically visualized and detected using the corresponding probes. Figure 5 and Figure 6 show representative micrographs of the fluorescent methanogenic and bacterial cells in the sludge sample double-stained with rhodamine-EUB338 and FITC-MSMX860. Solid and complex materials in digested sludge showed strong selffluorescence that pictures taken by a chilled CCD color camera with a modified RGB color balance helped distinguish the fluorescence of FITC-probes from the selffluorescence of the refuse materials. The self-fluorescence of refuse materials was yellowish in the fermented sample.

The presence of members of the Methanosaetaceae and Methanosarcinaceae in sludge was also in accordance with DGGE results but, the presence of Methanosarcinaceae was not detected by PCR-cloning. All aceticlastic methanogens belong to the order Methanosarcinales comprising two families, Methanosarcinaceae and Methanosaetaceae. Among six genera belonging to Methanosarcinaceae, the genus Methanosarcina can only utilize acetate as a substrate. All members of the family Methanosaetaceae are aceticlastic (Garrity and Holt, 2001). The Methanosaetaceae and Methanosarcinaceae families differ in their physiology, biokinetics, and growth environment with respect to acetate concentrations.

The family Methanosaetaceae has a high affinity for acetate accompanied with a relatively low growth rate, while the family Methanosarcinaceae has a much lower substrate affinity but with a higher growth rate. That describes why the POME anaerobic digester used in the present study was dominated by Methanosaetaceae as the acetate concentration in the sludge digester was favorable to them and acetate is the only substrate that supports the growth of Methanosaetaceae (Garrity and Holt, 2001).

The presence of members of the Methanosaetaceae in anaerobic bioreactors has been widely reported (Chan, 2001; Batstone et al. 2004; Hulshoff Pol et al. 2004). It is also generally known that the presence of Methanosaeta species leads to an improved granulation process and it results in a more stable bioreactor performance (Hulshoff Pol et al. 2004). The bioreactor used in this study was designed for continuous or intermittent mixing to maximize the contact between POME and the microbes. This differs from the upflow anaerobic sludge blanket (UASB) design in which granules are formed. However, Methanosaetaceae is assumed to form the initial nuclei followed by floc formation as well as described in Spaghetti Theory (Wiegant, 1987). Therefore, Methanosaetaceae plays an important role in floc formation in CDT and consequently higher performance of the bioreactor in terms of COD removal and methane production. However, this contrasts with the findings of Sallis and Uyanik (2003) indicating that associations between mixed bacterial populations and inert material formed the so-called nuclei at the initial stage of granule formation and the predominance of Methanosaetaceae occurred only when the granules had developed.

This methanogen is one of the main species responsible for the conversion of acetate to methane. Species within this family use acetate as their sole energy source, which is metabolized into methane and carbon dioxide. These organisms can be found in anaerobic sediments and anaerobic sludge bioreactors (Garrity and Holt, 2001). In order to maximize the efficiency of the bioreactor in terms 

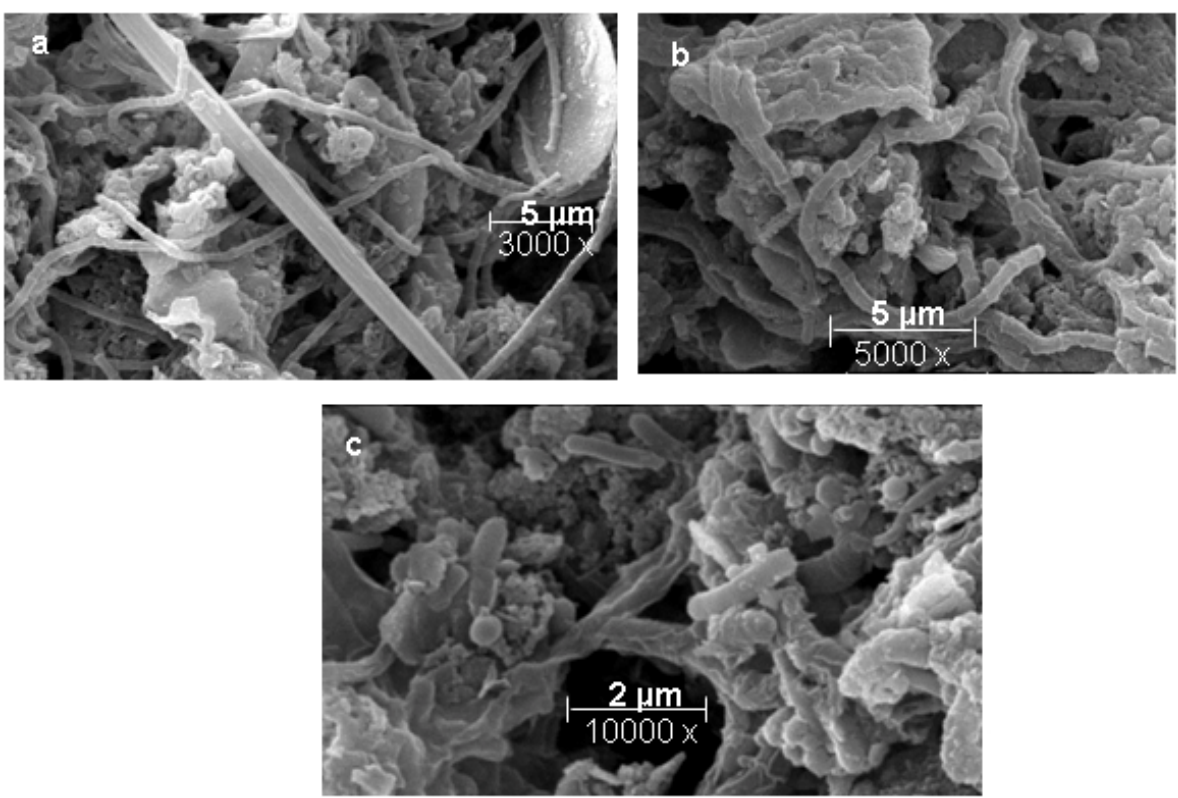

Figure 8. Scanning electron micrographs of sludge showing microorganisms in the flocs of POME sludge with a magnification of: (a) 3000 x; (b) 5000 x; (c) 10000 x; filamentous like Methanosaeta sp. was the dominant species recognized which play an important role in the formation of aggregates in CDT system.

of COD removal and methane production, optimized running operation e.g. organic loading rate (OLR) $(\mathrm{kg}$ $\mathrm{COD} / \mathrm{m}^{3} /$ day), $\mathrm{pH}$, alkalinity is of great importance. In this study, high COD removal $93 \%$ was observed which was higher than the findings of Choorit and Wisarnwan (2007) at mesophilic conditions. This was achieved due to a higher retention time (10 days) in comparison with 7 days used in their study. However, the methane production of 1.35 $\mathrm{L} / \mathrm{L}$ [reactor]/day was lower which could be attributed to a different bioreactor design (continuous stirred tank reactor (CSTR)) which enables higher application of OLR. Hence, higher methane production could be achieved.

\section{Quantification of methanogens by FISH}

The results of FISH counting showed that the total number of bacteria in the sludge sample was $1.4 \times 10^{5}$ cells $/ \mathrm{ml}$ sludge. The major group in the treated sludge sample was the Methanosaeta sp. which a count of $2 \times 10^{8}$ cells $/ \mathrm{ml}$ sludge. In contrast, the number of Methanosarcina sp. was almost 1000 times lower and was equal to that of bacteria. In other words, for each one thousand cells of Methanosaeta sp., there was just one single cell of Methanosarcina sp. present in the sludge. These results indicate that, the closed fermentation of POME led to the domination of Methanosaeta sp. in particular Methanosaeta concilii emphasizing on the importance of the substrate. The VFAs concentration of $517 \mathrm{mg} / \mathrm{L}$ showed high activity of methanogens which was reflected by high methane production $\left(56 \% \mathrm{v} / \mathrm{v}\right.$ methane of $1200 \mathrm{~m}^{3}$ biogas/day) and satisfactory COD removal of $93 \%$ (Table 1). The high number of methanogenic archaea $\left(2 \times 10^{8}\right.$ cells $/ \mathrm{ml}$ sludge $)$ in comparison with the bacteria cells $\left(1.4 \times 10^{5}\right.$ cells $/ \mathrm{ml}$ sludge) might be attributed to the stage of sampling at which the highest methane production was recorded.

The finding also showed that quantitative FISH using group and species specific rRNA-targeted probes could be applied to the direct analysis of semi-solid POME sludge to provide a good estimate of the dominant species of methanogens which plays an important role in optimizing running conditions of the digester for achieving the highest COD removal and methane production. The PCR-cloning, DGGE analysis and species-specific FISH confirmed that Methanosaeta concilii was the dominant species during the fermentation of POME.

\section{SEM}

The presence of Methanosaeta sp. in the studied industrial activated sludge was corroborated by its morphology using light microscopy (Figure 7). It has been reported that Methanosaeta sp. can form filaments of 10-300 cells (Garrity and Holt, 2001). The scanning electron microscopy provided a better resolution of Methanosaeta sp. than that obtained by conventional light microscopy. Filamentous like Methanosaeta sp. was observed and found to be the dominant species in the CDT system (Figure 8a; Figure 8b). It is clearly seen that the microorganisms bend around the organic matters and thus play an important roles in flocs/aggregate formation during POME treatment. Nevertheless, the actual size of the flocs or aggregates formed during the CDT process was not monitored. Methanosaeta sp. was normally determined to be at the core of the granules formation in UASB system (Hulshoff 
Pol et al. 2004). A demand to be strictly anaerobic and consume solely acetate makes them to be located at the core and other archaea-like Methanosarcina sp., fermentative and facultative bacteria are placed on the outer granules layer to prevent oxygen contamination (Savant et al. 2002). Some other microbes that coexisted in the digester are shown in Figure 8c. However, Methanosaeta-like microorganisms outnumbered short rods and cocci.

\section{CONCLUDING REMARKS}

In conclusion, our results indicate that filamentous acetateutilizing methanogens detected in anaerobic bioreactor treating POME belong to the genus Methanosaeta based on the cell-morphology, and the phenotypic and phylogenetic characteristics described above. The data obtained suggest that Methanosaeta concilii is the most abundant methanogen in POME anaerobic digestion and that it plays an important role in methane production from acetate and the optimum condition for its growth should be considered when an attempt is made to treat POME anaerobically. It also revealed the presence of possibly new strain of Methanosaeta in the bioreactor for treating POME.

\section{REFERENCES}

AMANN, R.I.; KRUMHOLZ, L. and STAHL, D.A. Fluorescent-oligonucleotide probing of whole cells for determinative, phylogenetic, and environmental studies in microbiology. Journal of Bacteriology, February 1990, vol. 172, no. 2, p. 762-770.

AMANN, R.I. In situ identification of micro-organisms by whole cell hybridization with rRNA-targeted nucleic acid probes. In: AKKERMANS, A.D.L.; ELSAS, J.D. and BRUIJN, F.J. eds. Molecular Microbial Ecology Manual. Dordrecht, Kluwer Academic Publisher, 1995, p. 1-15.

AMANN, R.I.; SNAIDR, J.; WAGNER, M.; LUDWIG, W. and SCHLEIFER, K.-H. In situ visualization of high genetic diversity in a natural microbial community. Journal of Bacteriology, June 1996, vol. 178, no. 12, p. 3496-3500.

American Public Health Association (APHA). Standard Methods for the Examination of Waters and Wastewaters, $21^{\text {st }}$ Ed., APHA, WCPF, AWWA, Washington DC, USA, 2005, $1368 \mathrm{p}$.

BATSTONE, D.J.; KELLER, J. and BLACKALL, L.L. The influence of substrate kinetics on the microbial community structure in granular anaerobic biomass. Water Research, March 2004, vol. 38, no. 6, p. 1390-1404.

BOURRAIN, Muriel; ACHOUAK, Wafa; URBAIN, Vincent and HEULIN, Thierry. DNA extraction from activated sludges. Current Microbiology, June 1999, vol. 38 , no. 6, p. 315-319.

CHAN, O.-C.; LIU, W.-T. and FANG, H.H. Study of microbial community of brewery-treating granular sludge by denaturing gradient gel electrophoresis of $16 \mathrm{~S}$ rRNA gene. Water Science and Technology, 2001, vol. 43, no. 1, p. 77-82.

CHOORIT, Wanna and WISARNWAN, Pornpan. Effect of temperature on the anaerobic digestion of palm oil mill effluent. Electronic Journal of Biotechnology, July 2007, vol. 10, no. 3, p. 376-385.

CROCETTI, Gregory; MURTO, Marika and BJÖRNSSON, Lovisa. An update and optimization of oligonucleotide probes targeting methanogenic Archaea for use in fluorescence in situ hybridization (FISH). Journal of Microbiological Methods, April 2006, vol. 65, no. 1, p. 194-201.

FOGEL, G.B.; COLLINS, C.R.; LI, J. and BRUNK, C.F. Prokaryotic genome size and SSU rDNA copy number: estimation of microbial relative abundance from a mixed population. Microbial Ecology, August 1999, vol. 38, no. 2, p. 93-113.

GARRITY, G.M. and HOLT, J.G. Phylum AII. Euryarchaeota phy. nov. In: BOONE, D.R. and CASTENHOLZ, R.W. eds. Bergey's Manual of Systematic Bacteriology. $2^{\text {nd }}$ Ed. New York, Springer, 2001, p. 211294. ISBN 0-387-98771-1.

HULSHOFF POL, L.W.; DE CASTRO LOPES, S.I.; LETTINGA, G. and LENS, P.N.L. Anaerobic sludge granulation. Water Research, March 2004, vol. 38, no. 6, p. 1376-1389.

KUMAR, Sudhir; TAMURA, Koichiro and NEI, Masatoshi. MEGA 3: integrated software for molecular evolutionary genetics analysis and sequence alignment. Briefings in Bioinformatics, 2004, vol. 5, no. 2, p. 150-163.

MAIDAK, B.L.; OLSEN, G.J.; LARSEN, N.; OVERBEEK, R.; MCCAUGHEY, M.J. and WOESE, C.R. The RDP (ribosomal database project). Nucleic Acids Research, January 1997, vol. 25, no. 1, p. 109-110.

MLADENOVSKA, Zuzana and AHRING, Kiaer Birgitte. Growth kinetics of thermophilic Methanosarcina spp. isolated from full-scale biogas plants treating animal manures. FEMS Microbiology Ecology, January 2000, vol. 31, no. 3, p. 225-229.

MOTER, Annette and GÖBEL, Ulf B. Fluorescence in situ hybridization (FISH) for direct visualization of microorganisms. Journal of Microbiological Methods, July 2000, vol. 41, no. 2, p. 85-112.

NAJAFPOUR, G.; YIENG, H.A.; YOUNESI, H. and ZINATIZADEH, A. Effect of organic loading on performance of rotating biological contactors using palm oil mill effluents. Process Biochemistry, 2005, vol. 40, no. 8, p. 2879-32884. 
PICENO, Y.M.; NOBLE, P.A. and LOVELL, C.R. Spatial and temporal assessment of diazotroph assemblage composition in vegetated salt marsh sediments using denaturing gradient gel electrophoresis analysis. Microbial Ecology, August 1999, vol. 38, no. 2, p. 157-167.

RONDON, Michele R.; AUGUST, Paul R.; BETTERMANN, Alan D.; BRADY, Sean F.; GROSSMAN, Trudy H.; LILES, Mark R.; LOIACONO, Kara A.; LYNCH, Berkley A.; MACNEIL, Ian A.; MINOR, Charles; TIONG, Choi Lai; GILMAN, Michael; OSBURNE, Marcia S.; CLARDY, Jon; HANDELSMAN, Jo and GOODMAN, Robert $\mathrm{M}$. Cloning the soil metagenome: a strategy for accessing the genetic and functional diversity of uncultured microorganisms. Applied and Environmental Microbiology, June 2000, vol. 66, no. 6, p. 2541-2547.

SAKAI, Kenji; MORI, Masatsugu; FUJI, Akira; IWAMI, Yuko; CHUKEATIROTE, Ekachai and SHIRAI, Yoshihito. Fluorescent in situ hybridization analysis of open lactic acid fermentation of kitchen refuse using rRNAtargeted oligonucleotide probes. Journal of Bioscience and Bioengineering, 2004, vol. 98, no. 1, p. 48-56.

SALLIS, P.J. and UYANIK, S. Granule development in a split-feed anaerobic baffled reactor. Bioresource Technology, September 2003, vol. 89, no. 3, p. 255-265.

SAVANT, D.V.; SHOUCHE, Y.S.; PRAKASH, S. and RANADE, D.R. Methanobrevibacter acididurans sp. nov., a novel methanogen from a sour anaerobic digester. International Journal of Systematic and Evolutionary Microbiology, July 2002, vol. 52, no. 4, p. 1081-1087.

SCHUPPLER, M.; WAGNER, M.; SCHÖN, G. and GÖBEL, U.B. In situ identification of nocardioform actinomycetes in activated sludge using fluorescent rRNAtargeted oligonucleotide probes. Microbiology, January 1998, vol. 144, no. 1, p. 249-259.

SEKIGUCHI, Yuji; TAKAHASHI, Hiroki; KAMAGATA, Yohichi; OHASHI, Akiyoshi and HARADA, Hideki. In situ detection, isolation, and physiological properties of a thin filamentous microorganism abundant in methanogenic granular sludges: a novel isolate affiliated with a clone cluster, the green non-sulfur bacteria, subdivision I. Applied and Environmental Microbiology, December 2001, vol. 67, no. 12 , p. 5740-5749.

THOMPSON, Julie D.; HIGGINS, Desmond G. and GIBSON, Toby J. CLUSTAL W: improving the sensitivity of progressive multiple sequence alignment through sequence weighting, position-specific gap penalties and weight matrix choice. Nucleic Acids Research, November 1994, vol. 22, no. 22, p. 4673-4680.

WATANABE, Kazuya; TERAMOTO, Maki; FUTAMATA, Hiroyuki and HARAYAMA, Shigeaki. Molecular detection, isolation, and physiological characterization of functionally dominant phenol-degrading bacteria in activated sludge. Applied and Environmental Microbiology, November 1998, vol. 64, no. 11, p. 43964402.

WATANABE, Kazuya; TERAMOTO, Maki and HARAYAMA, Shigeaki. An outbreak of nonflocculating catabolic populations caused the breakdown of a phenoldigesting activated sludge process. Applied and Environmental Microbiology, July 1999, vol. 65, no. 7, p. 2813-2819.

WATANABE, Takeshi; ASAKAWA, Susumu; NAKAMURA, Asumi; NAGAOKA, Kazunari and KIMURA, Makoto. DGGE method for analyzing $16 \mathrm{~S}$ rDNA of methanogenic archaeal community in paddy field soil. FEMS Microbiology Letters, 2004, vol. 232, no. 2, p. 153-163.

WIEGANT, W.M. The "spaghetti theory" on anaerobic sludge formation, or the inevitability of granulation. In: LETTINGA, G; ZEHNDER, A.J.B.; GROTENHUIS, J.T.C. and HULSHOFF POL, L.W. eds. Granular Anaerobic Sludge Microbiology and Technology: Proceedings of the GASMAT Workshop. Lunteren, The Netherlands, 1987, p. 146-152.

WRIGHT, André-Denis G. and PIMM, Carolyn. Improved strategy for presumptive identification of methanogens using $16 \mathrm{~S}$ riboprinting. Journal of Microbiological Methods, November 2003, vol. 55, no. 2, p. 337-349.

YACOB, Shahrakbah; SHIRAI, Yoshihito; HASSAN, Mohd Ali; WAKISAKA, Minato and SUBASH, Sunderaj. Start-up operation of semi-commercial closed anaerobic digester for palm oil mill effluent treatment. Process Biochemistry, April 2006, vol. 41, no. 4, p. 962-964. 